\title{
Comment on multi-dimensional indices
}

\author{
Nancy Birdsall
}

Published online: 27 August 2011

(C) Springer Science+Business Media, LLC 2011

Do composite indices (that combine various measures of different phenomena) have merit? The three Forum papers in the 2011 June issue of the Journal of Economic Inequality are rich in ideas and technically well-argued; they elucidate nicely fundamental conceptual as well as measurement issues.

Ravallion [9] argues the merits of the conventional single-dimension income or expenditure-based measure of poverty at the household level, as long as it is complemented with analysis incorporating non-market-price based dimensions of poverty such as schooling and health of household members (the "dashboard" view). Alkire and Foster [1] explain the logic of combining various dimensions of poverty into a multi-dimensional index, in which the initial identification of who is poor is based not solely on income or expenditures but on additional dimensions of being "poor", with transparent weights chosen for all dimensions. Klugman et al. [7] set out the logic of adjustments to the well-known Human Development Index (HDI), and argue the merits of the multi-dimensional HDI despite its inelegant combination of stocks and flows, and of inputs to well-being (income) and outcomes (schooling).

On the measurement of poverty, Ravallion's dashboard view wins in my reading, if only because it makes tradeoffs based on market prices explicit, and forces the analyst to make explicit tradeoffs on non-market goods in assessing who is poor. But I note that Alkire and Foster's emphasis on the joint distribution of various dimensions of poverty is fundamental and illustrates the benefits of a single data source at the household level. Incidentally, I would like to see an assessment of the relative sensitivity of identification of the poor to the World Bank's conventional measure of poverty (often without any accompanying dashboard statistical analysis), compared to one or another version of the Alkire and Foster approach, for a country over multiple years, using panel data. Does a multi-dimensional identification do better at understanding the fundamentals of long-term poverty and low inter-generational mobility within families?

\footnotetext{
N. Birdsall $(\bowtie)$

Center for Global Development, Washington, DC, USA

e-mail: NBirdsall@cgdev.org
} 
On the purposes of measurement and the merits of composite indices, there are, beyond describing and understanding the world for its own sake, three instrumental reasons for good measurement. Call them the technical policy rationale (to contribute to more effective policies at the technical level); the conversation-changer rationale (to alter the discourse on what matters in the first place); and the advocacy rationale (to communicate better, whether to acquire new or stronger advocates for change, or to name and shame relevant actors).

Though indices have to be technically defensible to be credible, many are constructed to be conversation-changers and advocacy tools. I see great merit in them as long as they are transparent about their construction (as are Klugman et al. and Alkire and Foster) and especially when they allow users to recalibrate them in terms of functional form, weights and so on (emphasized by Alkire and Foster) something relatively easy to do in a web-based world of low-cost computation. The HDI was originally proposed by ul Haq and Sen to change the conversation about development progress, which had been dominated by the World Bank's singular concern (until about 1990) with growth. They advocated a change from the focus on income to a focus on human development and on individuals' capabilities. Klugman et al. make clear that this is the purpose of the HDI; for example they call attention to the difference the HDI captures between convergence across countries on education and health compared to income (see [6] on that point). They also note that the HDI is not meant as a policy tool at the country level-that policymakers have far more information to exploit than the HDI captures (p. 31). The multi-dimensional poverty index has an advantage for communicating better than income alone the human suffering associated with multiple deprivations; Pakistan has more people that are MDI-poor than income-poor; Tanzania has far fewer.

Similarly, the country-level (rich countries) Commitment to Development Index of the Center for Global Development [10] is also a conversation-changer and communications tool. One purpose of it is to change a conversation mostly about aid to a conversation about migration, investment, climate and other actions by which rich countries affect the world's poor. And, like the HDI, the CDI provides rankings of countries; a horse race helps create an agenda for development advocates in rich countries to focus on changing their own countries' policies. The Doing Business Surveys and the governance index produced by World Bank analysts similarly communicate and advocate as well as measure; the QuODA quasi-index of CGD and the Brookings Institution ([2]; it ranks donors on the quality of their aid programs) also uses the horse-race.

Ironically, the simplicity of the single- dimension $\$ 1$ absolute poverty line (as justified in the [14] World Bank World Development Report) has had a conversationchanger and communications advantage as well, despite its shortcomings for measuring chronic poverty, as its widespread use for the subsequent 30 years amply illustrates.

All of the authors agree that the measures they describe and defend are inadequate as single measures of development or development progress. Relative income probably matters to people too ([3], preceded by [11], among many others), as does their potential upward mobility and that of their children [8]. The HDR team's newly revised inequality-adjusted HDI (HDII) and gender inequality-adjusted HDI are fine contributions (Peru suffers a 31\% loss in its potential human development due to inequality); Saudi Arabia suffers a $75 \%$ loss due gender inequality). Political and 
cultural and religious rights or lack thereof [12] matter for development, as does the sustainability of the natural environment [5]. For policy design, happiness and life satisfaction matter-whether adequately measured or not ([4]; and see [13] on that debate). What and how to measure, and why, will remain fundamental to a better understanding of development for many years to come.

\section{References}

1. Alkire, S., Foster, J.: Understandings and misunderstandings of multidimensional poverty measurement. J. Econ. Inequal. 9(2), 289-314 (2011)

2. Birdsall, N., Kharas, H.: Quality of official development assistance assessment (report). Center for Global Development. http://www.cgdev.org/content/publications/detail/1424481/ (2010)

3. Frank, R.: How Rising Inequality Harms the Middle Class. University of California Press, Los Angeles (2007)

4. Graham, C.: Happiness Around the World: The Paradox of Happy Peasants and Miserable Millionaires. Oxford University Press Inc., New York (2009)

5. Hamilton, K.: Where is the Wealth of Nations? Measuring Capital for the 21st Century. World Bank Publications, Washington, D.C. (2006)

6. Kenny, C.: Getting Better: Why Global Development is Succeeding-and How we can Improve the World even More. Basic Books, New York (2011)

7. Klugman, J., Rodríguez, F., Choi, H.-J.: The HDI 2010: new controversies, old critiques. J. Econ. Inequal. 9(2), 249-288 (2011)

8. Piketty, T.: Social mobility and redistributive politics. Q. J. Econ. 110(3), 551-584 (1995)

9. Ravallion, M.: On multidimensional indices of poverty. J. Econ. Inequal. 9(2), 235-248 (2011)

10. Roodman, D.: The commitment to development index: 2010 edition. Center for Global Development. http://www.cgdev.org/doc/CDI/2010/2010\%20files/Index\%20technical\%20paper\%202010. pdf (2010)

11. Smith, A.: The Theory of Moral Sentiments. A. Millar, London (1759)

12. United Nations Human Development Report: Cultural liberty in today's diverse world. United Nations Development Program (2004)

13. Wolfers, J., Stevenson, B.: Economic Growth and Subjective Well-Being: Reassessing the Easterlin Paradox. Brookings Institution (2008)

14. World Bank Development Report 1980: International Bank for Reconstruction and Development/The World Bank. Washington D.C. Available at: http://www-wds.worldbank. org/external/default/WDSContentServer/WDSP/IB/2000/12/13/000178830_98101911111283/ Rendered/PDF/multi_page.pdf (1980) 